\title{
Rosemary Essential Oils as a Promising Source of Bioactive Compounds: Chemical Composition, Thermal Properties, Biological Activity, and Gastronomical Perspectives
}

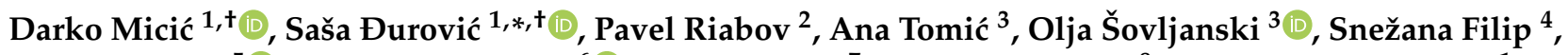 \\ Tomislav Tosti ${ }^{5}{ }^{\circ}$, Biljana Dojčinović ${ }^{6}\left(\mathbb{D}\right.$, Rade Božović ${ }^{7}$, Dušan Jovanović ${ }^{8}$ and Stevan Blagojević ${ }^{1}$ \\ 1 Institute of General and Physical Chemistry, Studentski trg 12/V, 11158 Belgrade, Serbia; \\ micic83@gmail.com (D.M.); stevan.blagojevic@gmail.com (S.B.) \\ 2 Federal State Budgetary Scientific Institution GOSMETODCENTR, Lusinovskaya 51, \\ 115093 Moscow, Russia; paryabov88@gmail.com \\ 3 Faculty of Technology, University of Novi Sad, Bulevar Cara Lazara 1, 21000 Novi Sad, Serbia; \\ anav@uns.ac.rs (A.T.); oljasovljanski@uns.ac.rs (O.̌̌.) \\ 4 Technical Faculty “Mihajlo Pupin” Zrenjanin, University of Novi Sad, Djure Djakovica bb, \\ 23000 Zrenjanin, Serbia; filipsnezana@gmail.com \\ 5 Faculty of Chemistry, University of Belgrade, Studentski trg 12 , \\ 11158 Belgrade, Serbia; tosti@chem.bg.ac.rs \\ check for \\ updates \\ Citation: Micić, D.; Đurović, S.; \\ Riabov, P.; Tomić, A.; Šovljanski, O.; \\ Filip, S.; Tosti, T.; Dojčinović, B.; \\ Božović, R.; Jovanović, D.; et al. \\ Rosemary Essential Oils as a \\ Promising Source of Bioactive \\ 6 Institute of Chemistry, Technology and Metallurgy-National Institute of the Republic of Serbia, \\ University of Belgrade, Njegoševa 12, 11000 Belgrade, Serbia; bmatic@chem.bg.ac.rs \\ 7 Faculty for Hotel and Tourism Management in Vrnjačka Banja, University of Kragujevac, \\ Vojvodjanska ulica bb, 36210 Vrnjačka Banja, Serbia; bozovicr@gmail.com \\ 8 Faculty of Agriculture, University of Novi Sad, Trg Dositeja Obradovica 8, \\ 21000 Novi Sad, Serbia; dusan.jov87@gmail.com \\ * Correspondence: sasatfns@uns.ac.rs; Tel.: +381-659577200 \\ + Both authors contributed equally to this work.
} Compounds: Chemical Composition, Thermal Properties, Biological Activity, and Gastronomical Perspectives. Foods 2021, 10, 2734 . https://doi.org/10.3390/foods 10112734

Academic Editor:

Verica Dragović-Uzelac

Received: 9 October 2021

Accepted: 3 November 2021

Published: 9 November 2021

Publisher's Note: MDPI stays neutral with regard to jurisdictional claims in published maps and institutional affiliations.

Copyright: (c) 2021 by the authors Licensee MDPI, Basel, Switzerland. This article is an open access article distributed under the terms and conditions of the Creative Commons Attribution (CC BY) license (https:/ / creativecommons.org/licenses/by/ $4.0 /)$.

\begin{abstract}
Rosemary (Rosmarinus officinalis L.) is a plant worldwide cultivated mainly for essential oils, extracts, and as a spice. Up-to-date results showed diversity in composition of the essential oils, which may influence their quality, biological activity, and thermal properties. Therefore, the aim of this study was to investigate the chemical composition, antimicrobial activity, and thermal properties of the rosemary essential oils originating from Serbia and Russia. Additionally, oils were added to the sunflower oils in order to investigate possible antioxidant activity during the frying. Investigation of the chemical profile marked $\alpha$-pinene, eucalyptol, and camphor as the most abundant compounds in both oils. However, overall composition influenced in such manner that Russian oil showed significantly higher antimicrobial activity, while Serbian oil proved to be better antioxidant agent in case of frying of sunflower oil. This would significantly influence possible application of the oils, which could be used as an antioxidant agent for extension of the food shelf life, or antimicrobial agent for protection against different microbial strains.
\end{abstract}

Keywords: rosemary essential oil; gastronomical perspectives; chemical composition; biological activity; DSC

\section{Introduction}

Rosmarinus officinalis L. (rosemary) is the plant from Lamiaceae family, genus Rsomarinus L. [1,2]. This plant is cultivated worldwide due to its essential oils, extracts, as a spice, and due to different biological activities [3]. Essential oils of this plant possess many pharmacological properties [2]. When it comes to the chemical profile, there are differences connected to the regionality, seasonality, environmental conditions, agronomic conditions, and varieties in rosemary itself [1-4]. In most cases, $\alpha$-pinene, eucalyptol, and camphor are major compounds in rosemary essential oil $[1,2,4,5]$. However, other compounds such as 
verbenone, borneol, camphor, and bornyl acetate were also reported as one of the principal compounds in the essential oil [6-8]. Consequences of such discrepancies in the chemical composition may be different level of biological activity and differences in behavior, i.e., thermal and other properties. These variations may significantly influence the quality and possibility of application of the essential oil. Therefore, it is very significant to monitor chemical composition during the prolonged period (years) in order to provide high quality of the oils for the market [2].

Sunflower oil is one of the most important and most common edible oils in the world together with soyabean, rapeseed, and cottonseed oils [9,10]. Although it is commonly used for the preparation of the food, this oil is susceptible to oxidation especially due to the presence of unsaturated fatty acids, e.g., linoleic and linolenic acids [11,12]. Oxidation may cause rancid odor, unpleasant flavor, discoloration, and many other products due to the secondary oxidation processes which further decrease nutritional quality and safety of the food $[10,11,13]$. Occurrence of the oxidation processes in the oils is influenced by several factors such as oxygen exposure, light, temperature, occurrence of the metals, e.g., Fe and $\mathrm{Cu}$ [14]. In order to prevent these processes and to prevent shelf-life of the sunflower oil, synthetic and natural antioxidants are added in [11,12]. The most common are butylated hydroxytoluene (BHT), butylated hydroxyanisole (BHA), and tertiary butyl hydroquinone (TBHQ) [12]. However, natural occurring antioxidants attract more and more attention due to the unwanted side effects of synthetic antioxidants [15]. Compounds such as polyphenolics and terpenes are potent antioxidants able to scavenge lipid radicals and to chelate metal ions $[12,14]$. Due to the well-known antioxidant activity of the essential oils, they were chosen as the natural antioxidant agent and their influence on the shelf-life was investigated by several research groups [9-12,16].

Because of the above-mentioned importance of monitoring the chemical composition and thermal properties of the essential oils, this study aimed to investigate chemical composition and thermal properties of the commercial essential oils from Serbia and Russia. For such purpose, Serbian and Russian rosemary essential oils were analyzed for chemical profile by the gas chromatography coupled with the mass spectrometry (GC/MS) and inductively coupled plasma coupled to the optical emission spectroscopy (ICP-OES). Thermal properties were investigated by differential scanning calorimetry (DSC). Additionally, biological activity was assessed by using four bacteria strains, one yeast, and one fungi strain. After the initial assessment, essential oils samples were added to the sunflower oil in different amounts for investigation of the possibility of their application as antioxidant agent during the frying process. Frying process was simulated on the DSC at the isothermal conditions at $140{ }^{\circ} \mathrm{C}$. To the best of our knowledge, this is the first time that DSC was used in such a study. Ability of the rosemary EO to scavenge free radicals could be successfully used for extension of the shelf life of the sunflower oil and/or to protect it from generation of radical species during the exposure to the elevated temperatures. Moreover, antimicrobial activity may also be a useful characteristic for possible application of the oil as a natural protective agent. Therefore, results presented herein will be of high importance for further implementation of essential oils.

\section{Materials and Methods}

\subsection{Chemicals and Reagents}

Both rosemary oils are available on the marked and obtained directly from the manufacturer. Serbian oil (SRB) was purchased from Herba Oils (Belgrade, Serbia). Russian oil (RF) was acquired from NPF Carstvo Aroma (Crimea, Russia). Sunflower oil was made by Dijamant DOO (Zrenjanin, Serbia) and is commercially available. All terpenes' standards were purchased from Sigma Aldrich and were analytical standard grade ( $\geq 99 \%)$. Methylene chloride was acquired from Centrohem and was of analytical grade purity. 


\subsection{GC/MS Analysis}

Analysis of essential oil (EO) samples was done with ion trap GCMS (Thermo Fisher, MA, USA). The analysis was performed using the well-known and described method $[17,18]$. TR WAX-MS $(30 \mathrm{~m} \times 0.25 \mathrm{~mm}, 0.25 \mu \mathrm{m})$ capillary column was used, while analyzed samples were dissolved in methylene chloride and injected into GC through TriPlus AS autosampler $(2 \mu \mathrm{L})$. Temperature program was as follows: initial temperature $45^{\circ} \mathrm{C}(8 \mathrm{~min})$, then $8.0^{\circ} \mathrm{C} / \mathrm{min}$ to $230^{\circ} \mathrm{C}(10 \mathrm{~min})$. Carrier gas was helium $(1 \mathrm{~mL} / \mathrm{min})$, while injector was operated in split mode (80:1). Injector, MS transfer line, and ion source temperatures were $250{ }^{\circ} \mathrm{C}, 200^{\circ} \mathrm{C}$, and $220^{\circ} \mathrm{C}$, respectively. Data acquisition was conducted in $m / z$ range of 30-300. Compounds were identified combining the NIST 08 MS database and MS spectra of analyzed standards (matching factors were higher than 850). Final results were expressed as relative percentage (\%). Quantitative analysis was performed by creating the calibration curves for analyzed compound in concentration range of $1.0-500.0 \mu \mathrm{g} / \mathrm{mL}$. The final content of compounds was expressed as milligram per gram of EO (mg/g EO).

\subsection{Contents of Major and Trace Elements}

The digestion of the sample of essential oils was performed on microwave system for digestion (Advanced Microwave Digestion System, Ethos 1, Milestone, Italy) equipped with the HPR-1000/10S high pressure segmented rotor. About $0.5 \mathrm{~g}$ of sample was precisely weighed with accuracy $\pm 0.1 \mathrm{mg}$ in placed in quartz inserts and mixed with of $5 \mathrm{~mL}$ HNO3 (65 wt.\%, Suprapur ${ }^{\circledR}$, Merck KGaA, Darmstadt, Germany). Temperature program of the microwave oven was as follows: increasing in the temperature up to $180{ }^{\circ} \mathrm{C}$ for $15 \mathrm{~min}$, maintaining it in the next $20 \mathrm{~min}$, following by the rapid decreasing to the room temperature. Obtained solution was further diluted with the ultrapure water to $25 \mathrm{~mL}$ in a volumetric flask. Presence and content of elements and minerals in the samples were established by the ICP-OES (iCAP 6500 Duo ICP, Thermo Fisher Scientific, Cambridge, $\mathrm{UK})$. Concentrations of elements of sample was expressed as $\mathrm{mg} / \mathrm{kg}$.

\subsection{Thermal Analysis}

The Q1000 Differential Scanning Calorimeter and Q500 Thermogravimetric Analyzer (TA Instruments, New Castle, DE, USA) were used for thermal analysis of RF and SRB EO. Acquired thermograms were analyzed using TA Advantage Universal analysis 2000 software (version 5.5.24).

\subsubsection{Thermal Characterization of EO}

The temperature range of the conducted DSC experiments was from 0 to $350{ }^{\circ} \mathrm{C}$. All experiments were conducted under the inert atmosphere (nitrogen) at flow of $50 \mathrm{~mL} / \mathrm{min}$. Samples $(3.0 \pm 0.3 \mathrm{mg})$ were heated at the rate of $5^{\circ} \mathrm{C} / \mathrm{min}$ in hermetic $\mathrm{Al}$ pans. Thermogravimetric experiments were performed in non-isothermal and isothermal conditions. Samples were weighted in $10.0 \pm 0.5 \mathrm{mg}$. Experiments were also conducted under the inert atmosphere (nitrogen with the flow of $60 \mathrm{~mL} / \mathrm{min}$ ). In the experiments at the nonisothermal conditions the samples were heated to $160^{\circ} \mathrm{C}$ at the rate $5^{\circ} \mathrm{C} / \mathrm{min}$. In isothermal conditions the samples were kept at $60^{\circ} \mathrm{C}$. Friedman's non-isothermal isoconversional methods [19] was used calculate the activation energy (Ea) of the evaporation of the tested EOs. Five heating rates were used for this purpose $\left(2,5,10,15\right.$, and $\left.20^{\circ} \mathrm{C} / \mathrm{min}\right)$. ICTAC Kinetics Committee recommendations for collecting kinetic data [20] and for performing kinetic computations [20] were followed when performing kinetic studies.

\subsubsection{Oxidative Stability of Sunflower Oil with Different Share of EO}

In order to examine the effect of adding EOs on the oxidative stability of sunflower oil, five concentrations $(0.1,0.5,1,5$ and $10 \%(w / w))$ of RF and SRB EO in sunflower oil were made. Sunflower oil without the addition of EO was used as a control sample. The oxidative stability of all sunflower oil samples was determined by measuring the oxidation induction time (OIT) using the DSC method [21], at $140{ }^{\circ} \mathrm{C}$ and under oxygen flow of 
$50 \mathrm{~mL} / \mathrm{min}$. Open aluminum pans were used, and mass of samples was $3.0 \pm 0.3 \mathrm{mg}$. OIT represents the time from the heating of the oil sample at a certain isothermal temperature to the beginning of the oxidation process in it. The higher OIT values indicate that the analyzed oil sample is more oxidatively stable.

\subsection{Antimicrobial Activity of Samples}

In this study, the antimicrobial activity of the tested R. officinalis EO was tested against four bacteria-two Gram negative: E. coli (ATCC 25922) and P. aeruginosa (ATCC 27853) and two Gram positive: B. cereus (ATCC 11778) and S. aureus (ATCC 25923). Moreover, the antimicrobial potential of the selected oils on eukaryotic type of cells was examined on S. cerevisiae (ATCC 9763) and A. brasiliensis (ATCC 16404). All strains were obtained from the American Type Culture Collection and the cultures were kept frozen at $-80{ }^{\circ} \mathrm{C}$ in cryovials with the addition of glycerol as a cryoprotectant.

For the assessment of the antimicrobial activity of the R. officinalis EO two methods have been employed: disc diffusion method and microdilution method for determination of minimum inhibitory concentration (MIC). Both methods were previously described in details [22,23].

Bacterial strains were grown on Müller-Hinton agar (HiMedia, Mumbai, India) at $37^{\circ} \mathrm{C}$ for $24 \mathrm{~h}$ and at $30^{\circ} \mathrm{C}$ (Bacillus cereus ATCC 11,778 and Bacillus cereusw) for $18 \mathrm{~h}$. Yeast strains were grown on Sabouraud Maltose agar (HiMedia, Mumbai, India) at $25{ }^{\circ} \mathrm{C}$ (Saccharomyces cerevisiae ATCC 9763) or at $37^{\circ} \mathrm{C}$ (Candida albicans ATCC 10231) for $48 \mathrm{~h}$. Cells were suspended in a sterile $0.9 \% \mathrm{NaCl}$ solution. Suspensions were adjusted to a concentration of $1 \cdot 106 \mathrm{cfu} / \mathrm{mL}$ (estimated by Densichek; BioMérieux, Marcy-l'Étoile, France). Afterwards, $2 \mathrm{~mL}$ of the prepared suspensions for inoculation were homogenized with $18 \mathrm{~mL}$ of melted $\left(45^{\circ} \mathrm{C}\right)$ media (the same as for suspension preparation) and poured into Petri dishes. After the solidification, four sterile discs (6 mm in diameter) (HiMedia, Mumbai, India) were placed onto the previously inoculated agar plates. Applied disks were impregnated with $15 \mu \mathrm{L}$ of the EO dissolved in dimethyl sulfoxide $(50 \mathrm{mg} / \mathrm{mL})$. Dimethyl sulfoxide was used as negative control, while chloramphenicol, tetracycline, and actiodion were used as a positive control After the incubation period, the diameter of the inhibition halo zone was measured for each disk using HiAntibiotic Zone Scale ${ }^{\mathrm{TM}}$ (HiMedia, Mumbai, India). Each experiment was performed in triplicate $(n=3)$.

Minimal inhibitory concentration was assessed for gram-positive bacteria using the microdilution method in sterile flat-bottom 96-well microtiter plates. The preparation procedure of suspensions for inoculation is previously described Disk diffusion method. $1 \mathrm{~mL}$ of the prepared suspension $\left(1 \times 10^{6} \mathrm{cfu} / \mathrm{mL}\right)$ was homogenized with $9 \mathrm{~mL}$ of MüllerHinton broth (HiMedia, Mumbai, India). In order to obtain final concentration in each well $(n=3), 100 \mu \mathrm{L}$ of inoculated media were mixed with $100 \mu \mathrm{L}$ of extract dilutions. In each test microtiter plate, there were a positive control (inoculated media without extracts) and a negative control $(100 \mu \mathrm{L}$ of medium mixed with $100 \mu \mathrm{L}$ of extracts). All test plates were incubated for $24 \mathrm{~h}$ at $37^{\circ} \mathrm{C}$ or at $30^{\circ} \mathrm{C}$ (Bacillus strains). Afterwards, a $100 \mu \mathrm{L}$ aliquot was poured into Petri dishes and homogenized with Plate Count agar (HiMedia, Mumbai, India). Petri dishes were incubated under identical conditions as microtiter plates and the colonies were enumerated by viable count following the incubation period.

Minimal inhibitory concentration (MIC) is known as the lowest concentration of antimicrobial agent that, under defined in vitro conditions, prevents the appearance of visible growth of a microorganism within a defined period of time. MIC is usually calculated as $100 \times(\mathrm{Nc}-\mathrm{Nt}) / \mathrm{Nc}(\%)$, where Nc and Nt are numbers of cells of positive control and treatment, respectively.

\subsection{Statistical Analysis}

All measurements in this study had been performed in triplicates. $t$-test and analysis of variance (ANOVA) followed by Tukey's HSD test $(p<0.05)$ were used for the statistical analysis. In the OIT results, it was analyzed whether the adding EO had an antioxidative 
or prooxidative effect compared to sunflower oil without EO, how the concentration of added EO affected the OIT values, and how the type of EO affected the OIT values. All samples that had a statistically significantly higher or lower OIT value (antioxidative and prooxidative effect, respectively) than pure sunflower oil were marked with an asterisk in superscript. Different uppercase letters in the same EO indicate a significant difference of the OIT depending on the concentration of the added EO. Different lowercase letters in the same concentration of the added EO indicate a significant difference of the OIT depending on the type of EO. XLSTAT (version 2014.5.03, Addinsoft, New York, NY, USA) and statistics add-in for MS Excel were used to perform above-mentioned statistical calculations.

\section{Results}

\subsection{Chemical Profiles of Essential Oils}

Both Serbian (SRB) and Russian (RF) rosemary oils were analyzed for assessment of chemical profile and composition of terpenes, minerals, and elements. Result of the GC/MS analysis is given in Table 1, while chromatograms are given in Figure S1 (Supplementary Data).

Table 1. Chemical profile, relative content (\%), and quantitative profile of Serbian (SRB) and Russian (RF) rosemary essential oil.

\begin{tabular}{|c|c|c|c|c|}
\hline \multirow[b]{2}{*}{ Compound } & \multicolumn{2}{|c|}{ SRB } & \multicolumn{2}{|c|}{ RF } \\
\hline & $\begin{array}{c}\text { Content } \\
(\%)\end{array}$ & Content (mg/g EO) & $\begin{array}{c}\text { Content } \\
(\%)\end{array}$ & $\begin{array}{l}\text { Content } \\
\text { (mg/g EO) }\end{array}$ \\
\hline \multicolumn{5}{|c|}{ Cyclic monoterpenes } \\
\hline Myrcene & 2.43 & $3.9 \pm 0.1^{\mathrm{a}}$ & 0.05 & $0.15 \pm 0.02^{b}$ \\
\hline \multicolumn{5}{|c|}{ Cyclic monoterpenes } \\
\hline$\alpha$-Thujene & 0.39 & - & 0.55 & - \\
\hline$\alpha$-Pinene & 23.00 & $282 \pm 5^{a}$ & 17.76 & $122 \pm 1^{b}$ \\
\hline$\alpha$-Fenchene & 0.09 & - & 0.22 & - \\
\hline Camphene & 9.99 & - & 8.36 & - \\
\hline$\beta$-Pinene & 3.49 & $49.9 \pm 0.9^{a}$ & 5.19 & $37.7 \pm 0.2^{b}$ \\
\hline$\alpha$-Phellandrene & 0.59 & - & N.D. * & - \\
\hline$\beta$-Phellandrene & 0.13 & - & N.D. & - \\
\hline$\alpha$-Terpinene & 0.25 & $26.4 \pm 0.3$ & ND. & - \\
\hline Limonene & 4.18 & $63.4 \pm 0.5^{\mathrm{a}}$ & 3.11 & $27.4 \pm 0.3^{b}$ \\
\hline$\gamma$-Terpinene & 0.43 & $5.1 \pm 0.1$ & N.D. & - \\
\hline Terpinolene & 0.48 & - & N.D. & - \\
\hline \multicolumn{5}{|c|}{ Acyclic oxygenated mnoterpenes } \\
\hline Linalool & 0.85 & $15.6 \pm 0.2^{\mathrm{a}}$ & 0.84 & $10.0 \pm 0.1^{b}$ \\
\hline \multicolumn{5}{|c|}{ Cyclic oxygenated monoterpenes } \\
\hline Eucalyptol & 17.79 & $177 \pm 3^{a}$ & 23.40 & $169 \pm 2^{b}$ \\
\hline$\alpha$-Pinene oxide & N.D. & - & 0.47 & - \\
\hline Fenchone & 0.01 & $0.02 \pm 0.00^{b}$ & 0.02 & $0.86 \pm 0.05^{\mathrm{a}}$ \\
\hline$\alpha$-Campholenal & N.D. & - & 0.58 & - \\
\hline Isothujol & 0.02 & - & N.D. & - \\
\hline Camphor & 14.39 & $149 \pm 3^{\mathrm{a}}$ & 17.17 & $104 \pm 2^{b}$ \\
\hline Bornyl acetate & 2.39 & $22.5 \pm 0.3^{\mathrm{a}}$ & 3.31 & $19.3 \pm 0.1^{b}$ \\
\hline Pinocarvone & N.D. & - & 0.20 & - \\
\hline Terpinen-4-ol & 1.19 & $14.8 \pm 0.1$ & N.D. & - \\
\hline Myrtenal & 0.04 & - & 0.33 & - \\
\hline cis-Sabinol & 0.08 & - & 0.14 & - \\
\hline Isoborneol & N.D. & - & 0.11 & $0.61 \pm 0.02$ \\
\hline$\alpha$-Terpineol & 2.30 & $51.0 \pm 0.5$ & N.D. & - \\
\hline Borneol & 2.39 & $20.2 \pm 0.2^{b}$ & 4.56 & $27.7 \pm 0.3^{\mathrm{a}}$ \\
\hline Carvone & N.D. & - & 0.07 & $3.86 \pm 0.06$ \\
\hline
\end{tabular}


Table 1. Cont.

\begin{tabular}{|c|c|c|c|c|}
\hline \multirow[b]{2}{*}{ Compound } & \multicolumn{2}{|c|}{ SRB } & \multicolumn{2}{|c|}{ RF } \\
\hline & $\begin{array}{c}\text { Content } \\
(\%)\end{array}$ & Content (mg/g EO) & $\begin{array}{c}\text { Content } \\
(\%)\end{array}$ & $\begin{array}{l}\text { Content } \\
\text { (mg/g EO) }\end{array}$ \\
\hline Myrtenol & 0.21 & - & 0.25 & - \\
\hline trans-Carveol & 0.17 & - & 0.05 & - \\
\hline$p$-Cymene-8-ol & N.D. & - & 0.08 & - \\
\hline Verbenone & 2.33 & - & 0.30 & - \\
\hline cis-Verbenol & 0.15 & - & 0.25 & - \\
\hline \multicolumn{5}{|c|}{ Cyclic aromatic monoterpenes } \\
\hline$p$-Cymene & 4.51 & $33.6 \pm 0.4^{\mathrm{b}}$ & 10.91 & $41.3 \pm 0.4^{\mathrm{a}}$ \\
\hline$m$-Cymene & N.D. & - & 0.02 & $0.07 \pm 0.01$ \\
\hline \multicolumn{5}{|c|}{ Sesquiterpenes } \\
\hline$\alpha$-Copaene & 0.18 & - & 0.03 & - \\
\hline$\alpha$-Cubebene & 0.12 & - & 0.07 & - \\
\hline trans- $\beta$-Caryophyllene & 3.22 & $29.7 \pm 0.2^{\mathrm{a}}$ & 0.63 & $4.06 \pm 0.09^{b}$ \\
\hline Humulene & 1.22 & - & N.D. & - \\
\hline Caryophyllene oxide & 0.47 & - & 0.97 & - \\
\hline \multicolumn{5}{|c|}{ Other } \\
\hline 2-Methyl-3-octanone & 0.44 & - & N.D. & - \\
\hline 3-Octanol & 0.03 & - & N.D. & - \\
\hline 1-Octen-3-ol & 0.08 & - & N.D. & - \\
\hline
\end{tabular}

The values are presented as mean $\pm \mathrm{SD}$, different superscripts within the same row indicate significant differences of means, according to $t$-test $(p<0.05) .{ }^{*}$ N.D. - Not detected. "-" not determined.

Obtained results showed that three compounds were principle in both essential oils: $\alpha$-pinene (23.00\% and $17.76 \%$ in SRB and RF oils, respectively), eucalyptol (17.79\% and 23.40 in SRB and RF oils, respectively), and camphor (14.39\% and $17.17 \%$ in SRB and RF oils, respectively). Both eucalyptol and camphor were found in higher percentage in RF compared to the SRB oil. However, quantification showed that all three compounds were presented in higher amount in SRB oil. Beside above-mentioned compounds, there were several compounds detected in higher amount: camphene, $\beta$-pinene, limonene, $p$-cymene, borneol, bornyl acetate, and trans- $\beta$-caryophyllene.

Results also showed certain diversity in chemical profile between the samples. Thus, $\alpha$-terpineol and terpinen-4-ol were found only in SRB sample. Moreover, several other compounds, such as $\gamma$-terpinene, $\alpha$ - and $\beta$-phellandrenes, terpinolene, were also found only in SRB oil sample. On the other hand, m-cymene, $\alpha$-pinane oxide, pinocarvone, carvone, and several other compounds were detected in RF sample (Table 1). It is expected that this diversity in profile would influence their behavior and biological activity.

Previously reported studies about the chemical composition of rosemary essential oils showed also certain diversity in chemical profile and composition. Pellegrini et al. (2018) found camphor to be the principal compound (22.07\%) followed by $\alpha$-pinene $(16.64 \%)$, eucalyptol (15.71\%), and borneol (11.99\%) [5]. Interestingly, authors reported absence of limonene in this sample, while borneol was significantly higher than in our samples. Investigation of seasonal diversity in composition of the rosemary oil showed changes in the content and overall profile of analyzed samples [2]. Despite these changes, camphor was reported as the principal compound (35.93-24.38\%) followed by eucalyptol (19.26-22.68\%), and myrcene $(9.55-15.25 \%)$. Similar results were obtained by Zaouali et al. [1], but with eucalyptol as the principal compound in most cases. Bajalan et al. (2007) investigated composition of rosemary oils isolated from seven Iranian populations of this plant. However, despite differences in EO's sources, authors confirmed the prevalence of camphor, eucalyptol, and $\alpha$-pinene [4]. The same case was for study reported by Jordan et al. (2013), where authors investigated influence of phenological stage on chemical composition of rosemary essential oil. Major compounds were the same, i.e., $\alpha$-pinene (13.0-15.5\%), eucalyptol 
(18.9-21.2\%), and camphor (17.0-18.6\%) [3]. Bousbia et al. (2009) applied two different approaches for isolation of essential oil, i.e., hydrodistillation and microwave hydrodifussion and gravity, and compared chemical profile of obtained samples. Results were similar when comparing to each other, where $\alpha$-pinene was the principal compound, followed by camphor and verbenone. However, authors did not report presence of eucalyptol, which is one of the main compounds in our samples [8]. Karakaya et al. (2014) also investigated effects of different extraction techniques (hydrodistillation and microwave-assisted hydrodistillation) on the composition of the rosemary oil. They found eucalyptol to be the principal compound, followed by camphor, $\alpha$-pinene, borneol, and camphene [7]. There is also study of composition of commercial essential oil [6], which also reported camphor to be the main compound (35.5\%), followed by eucalyptol (18.2\%). Surprisingly, authors reported rather high content of bornyl acetate (13.4\%) and lower content of $\alpha$-pinene (4.9\%) comparing to the results from this study (Table 1).

Although most studies reported the same major compounds, there were other studies which reported slightly different composition. Thus, Bozin et al. (2007) reported limonene $(21.7 \%)$ and camphor $(21.6 \%)$ as the principal compounds in essential oils sample [24]. Authors detected eucalyptol in $2.1 \%$, but found linalool oxide in $10.8 \%$. Camphene was reported in lower percentage (3.9\%), as well as $\beta$-pinene $(1.1 \%)$. Besides content, samples were differing in composition, where authors reported compounds which were not found herein [24]. Gachkar et al. (2007) also reported significantly different composition of rosemary oil [25]. Piperitone was the main compound (23.7\%) followed by $\alpha$-pinene $(14.9 \%)$ and linalool (14.9\%). Content of eucalyptol and camphor were $7.43 \%$ and $4.97 \%$, respectively, which is significantly lower content comparing to our findings (Table 1).

Elements and mineral's content are given in Table 2. It might be seen that SRB was quite rich in $\mathrm{Fe}, \mathrm{Ca}, \mathrm{Na}$, and $\mathrm{S}$, while $\mathrm{RF}$ was rich in $\mathrm{Ca}, \mathrm{Na}$, and $\mathrm{S}$. Comparing the results of these elements, SRB was richer in their content. Arsenic was not found in both samples, while Co was found only in SRB sample in trace level $(0.032 \mathrm{mg} / \mathrm{kg})$. Furthermore, $\mathrm{Cd}$ and $\mathrm{Pb}$ were also detected in trace levels, what makes these oils safe to use in a diet or as a supplement.

There are several available classifications of elements. One of them classifies elements into four major groups: essential, beneficial, contaminating, and polluting elements [26]. According to Stephanos and Addison essential elements are certain nonmetals $(\mathrm{C}, \mathrm{H}, \mathrm{O}, \mathrm{N}$, $\mathrm{S}, \mathrm{P}, \mathrm{Cl}$, and I), alkali and alkaline-earth metals ( $\mathrm{Na}, \mathrm{K}, \mathrm{Mg}$, and $\mathrm{Ca}$ ), and transition elements such as $\mathrm{Fe}, \mathrm{Zn}, \mathrm{Mn}, \mathrm{Cu}, \mathrm{Co}$, and $\mathrm{Mo}$. In the group of beneficials are different nonmetals, metalloids, and metals (F, Br, Se, Si, Sn, V, Cr, and Ni. Polluting elements are $\mathrm{Hg}, \mathrm{Cd}$, and $\mathrm{Pb}$. Presence of certain elements, such as $\mathrm{Fe}, \mathrm{Ca}, \mathrm{Cr}$, and $\mathrm{Mg}$, is essential for nutritive value of the essential oils. Bulk elements are necessary for the proper functioning of the organism and should be intake at the daily levels. Iron is an essential microelement necessary for hemoglobin and myoglobin synthesis. Besides those two proteins, iron is also essential for cytochromes and some other enzymes. The deficiency of this element is known as anemia. Several types of enzymes require zinc for proper functioning. These are hydrolases, peptidases, and oxidases. This element has also significant role in gene expression and fold stabilization which requires zinc fingers [27]. Copper has also important role in metabolism, i.e., in the electron transfer process in Type III heme-copper oxidases and also Type I blue-copper proteins [28]. All these elements should be ingested daily. Because of such importance, daily intake levels are defined and known as dietary reference intake (DRI) created by the US Department of Agriculture [29]. According to the DRI, daily intake of $\mathrm{Na}$ and $\mathrm{K}$, and $\mathrm{Ca}$ is measured in grams, while intake of $\mathrm{Mg}$ should be in milligrams. Daily intake of phosphorus is $1.25 \mathrm{~g} /$ day for both male and female up to 18 years old. After this age, uptake of this element should be lower ( $700 \mathrm{mg} /$ day). Iron, zinc, and manganese should be also taken in milligrams a day levels, while copper and chromium should be ingested in micrograms a day levels [29]. 
Table 2. Elements and minerals in Serbian (SRB) and Russian (RF) essential oil.

\begin{tabular}{ccc}
\hline Element (mg/kg) & SRB & RF \\
\hline B & Bulk elements & \\
\hline $\mathrm{Na}$ & $1.14 \pm 0.08^{\mathrm{a}}$ & $1.26 \pm 0.05^{\mathrm{a}}$ \\
$\mathrm{Mg}$ & $8.46 \pm 0.15^{\mathrm{a}}$ & $8.17 \pm 0.36^{\mathrm{a}}$ \\
$\mathrm{Ca}$ & $1.18 \pm 0.09^{\mathrm{a}}$ & $0.89 \pm 0.01^{\mathrm{b}}$ \\
\hline $\mathrm{Co}$ & $7.21 \pm 0.23^{\mathrm{b}}$ & $9.90 \pm 0.20^{\mathrm{a}}$ \\
\hline $\mathrm{Cr}$ & Trace elements & \\
$\mathrm{Cu}$ & $0.032 \pm 0.001$ & $\mathrm{~N} . \mathrm{D} .^{*}$ \\
$\mathrm{Fe}$ & $9.50 \pm 0.02^{\mathrm{a}}$ & $0.025 \pm 0.002^{\mathrm{b}}$ \\
$\mathrm{Li}$ & $0.132 \pm 0.009^{\mathrm{a}}$ & $0.041 \pm 0.005^{\mathrm{b}}$ \\
$\mathrm{Mn}$ & $5.66 \pm 0.04^{\mathrm{a}}$ & $1.58 \pm 0.17^{\mathrm{b}}$ \\
$\mathrm{Al}$ & $0.022 \pm 0.002^{\mathrm{a}}$ & $0.012 \pm 0.001^{\mathrm{b}}$ \\
$\mathrm{Sr}$ & $0.261 \pm 0.009^{\mathrm{a}}$ & $0.022 \pm 0.002^{\mathrm{b}}$ \\
$\mathrm{Ba}$ & $0.83 \pm 0.03^{\mathrm{a}}$ & $0.81 \pm 0.09^{\mathrm{a}}$ \\
$\mathrm{Ni}$ & $0.020 \pm 0.004^{\mathrm{a}}$ & $0.012 \pm 0.002^{\mathrm{a}}$ \\
$\mathrm{Zn}$ & $0.05 \pm 0.02^{\mathrm{a}}$ & $0.004 \pm 0.001^{\mathrm{a}}$ \\
$\mathrm{Se}$ & $2.06 \pm 0.01^{\mathrm{a}}$ & $0.23 \pm 0.02^{\mathrm{b}}$ \\
$\mathrm{P}$ & $0.048 \pm 0.001^{\mathrm{b}}$ & $0.107 \pm 0.012^{\mathrm{a}}$ \\
$\mathrm{S}$ & $0.44 \pm 0.07^{\mathrm{a}}$ & $0.47 \pm 0.10^{\mathrm{a}}$ \\
$\mathrm{Pb}$ & $1067 \pm 2^{\mathrm{a}}$ & $1053 \pm 10^{\mathrm{a}}$ \\
$\mathrm{As}$ & $53.61 \pm 0.08^{\mathrm{a}}$ & $6.06 \pm 0.04^{\mathrm{b}}$ \\
$\mathrm{Cd}$ & Polluting elements & \\
\hline
\end{tabular}

The values are presented as mean $\pm S D$, different superscripts within the same row indicate significant differences of means, according to $t$-test $(p<0.05) .{ }^{*}$ N.D. - Not detected.

\subsection{Antimicrobial Activity of Essential Oils}

The next step of this study was to investigate whether the variation in chemical composition and geographical origin of the tested R. officinalis EO affect their antimicrobial potential. Preliminary screening of the in vitro antimicrobial activity was performed by disc-diffusion method. According to the obtained results (Table 3) it might be noticed that $\mathrm{RF}$ showed far better antimicrobial potential in comparison to the SRB. In the case of RF, the maximum inhibition zone of $40.00 \mathrm{~mm}$ was registered for all tested microorganisms, except for $P$. aeruginosa $(21.33 \mathrm{~mm})$ and A. brasiliensis $(33.00 \mathrm{~mm})$ where the activity might be estimated as moderate to high. Additionally, it should be pointed out that the inhibition zone of RF was even higher than those of the used positive controls (chloramphenicol $30 \mu \mathrm{g} /$ disc, tetracycline $30 \mu \mathrm{g} / \mathrm{disc}$, and actidion $30 \mu \mathrm{g} / \mathrm{disc}$ ), indicating the possibility of using RF as a natural ingredient in combating the microbial and antimycotic resistance toward the antibiotics. A high antimicrobial activity (above $30.00 \mathrm{~mm}$ ) was also observed for SRBR against $E$. coli, S. aureus, and S. cerevisiae. However, this oil showed low to moderate activity against the other tested microorganisms. According to the relevant researches conducted in this area, it can be concluded that rosemary EO usually demonstrated moderate activity against tested set of microorganisms $[1,2,6]$, which is consistent to the results obtained for SRB. To the best of our knowledge, such a high antimicrobial performance of rosemary EO as in the case of RF has not been previously published elsewhere. In the available literature, there are opposite opinions about the carriers of antimicrobial activity in EOs. Some of the authors claim that the dominant chemical components are essential for antimicrobial properties such as camphor, eucalyptol, and $\alpha$-pinene [1,30]. On the other hand, there are studies which emphasize the importance of minor components in EOs as well as the synergistic effect between terpenoid and phenolic compounds which could be able to disrupt cellular membrane and inhibit cell respiration and ion transport process [3,31]. 
Table 3. Antimicrobial activity of R. officinalis EO from Serbia (SRB) and Russia (RF) (mean value diameter of the inhibition zone $(\mathrm{mm})$ including disc $(6 \mathrm{~mm})) \pm$ standard deviation).

\begin{tabular}{|c|c|c|c|c|c|c|c|}
\hline \multirow{3}{*}{ Group } & \multirow{3}{*}{$\begin{array}{l}\text { Tested } \\
\text { Strains }\end{array}$} & \multirow{2}{*}{\multicolumn{2}{|c|}{$\begin{array}{c}\text { Disk Diffusion Method } \\
(15 \mu \mathrm{L} \text { of EO Concentration } 100 \%)\end{array}$}} & \multicolumn{3}{|c|}{ Positive Control } & \multirow{3}{*}{$\begin{array}{c}\text { Negative } \\
\text { Control }\end{array}$} \\
\hline & & & & An & oiotic/Antim & tic & \\
\hline & & SRB & RF & CHL & TET & Actidion & \\
\hline \multirow{2}{*}{ G(-) bacteria } & $\begin{array}{c}\text { E.coli } \\
\text { ATCC } 25922\end{array}$ & $32 \pm 3^{b}$ & $40.0 \pm 0.0^{\mathrm{a}}$ & $29 \pm 2^{b}$ & $21.0 \pm 0.0^{c}$ & - & nd * \\
\hline & $\begin{array}{l}\text { P. aeruginosa } \\
\text { ATCC } 27853\end{array}$ & $10.0 \pm 0.0^{c}$ & $21 \pm 3^{a}$ & $12.3 \pm 0.6^{b c}$ & $14.7 \pm 0.6^{b}$ & - & nd \\
\hline \multirow{2}{*}{$\mathrm{G}(+)$ bacteria } & $\begin{array}{c}\text { B. cereus } \\
\text { ATCC } 11778\end{array}$ & $12 \pm 1^{\mathrm{d}}$ & $40.0 \pm 0.0^{a}$ & $30.3 \pm 0.6^{b}$ & $28 \pm 1^{c}$ & - & nd \\
\hline & $\begin{array}{c}\text { S. aureus } \\
\text { ATCC } 25923\end{array}$ & $32 \pm 2^{b}$ & $40.0 \pm 0.0^{\mathrm{a}}$ & $29.7 \pm 0.6^{b}$ & $26.0 \pm 0.0^{c}$ & - & nd \\
\hline Yeast & $\begin{array}{l}\text { S. cerevisiae } \\
\text { ATCC } 9763\end{array}$ & $33 \pm 2^{b}$ & $40.0 \pm 0.0^{\mathrm{a}}$ & - & - & $40.0 \pm 0.0^{\mathrm{a}}$ & nd \\
\hline Fungi & $\begin{array}{l}\text { A. brasiliensis } \\
\text { ATCC } 16404\end{array}$ & $11 \pm 2^{c}$ & $33.0 \pm 0.0^{\mathrm{a}}$ & - & - & $26.3 \pm 0.6^{b}$ & nd \\
\hline
\end{tabular}

Values are presented as mean \pm standard deviation $(n=3)$, different lowercase superscript within the same row indicate a significant difference of means according to Tukey's honest significant difference (HSD) test $(p<0.05)$. CHL-chloramphenicol, TET-tetracycline, DMSO-dimethyl sulfoxide. * nd-not detected.

When it comes to the composition-activity relationship, i.e., structure-activity dependence, it was shown that isomerism does not influences the antimicrobial activity. It has been also reported that functional group's position does not affect the activity. However, occurrence of the hydroxyl functional group in the structure has significant impact on the antimicrobial activity [32]. Therefore, alcohols are more active than aldehydes [33,34]. Furthermore, terpinen-4-ol proved to be a more potent antimicrobial agent than $\alpha$-terpineol. Explanation for such behavior is the capacity for creating the hydrogen bonds. In this case, position of $\mathrm{OH}$ group in 4-terpineol increases the capacity for making the hydrogen bond [32]. Cyclic monoterpenes $\beta$-pinene and limonene also showed significant activity. Thus, $\beta$-pinene influences the respiration and leakage of the potassium and hydrogen ions in yeasts [35], while both compounds inhibit energy-dependent processes, such as respiration, in S. cerevisiae [36]. Certain terpenes, e.g., $\alpha$ - and $\beta$-pinene, $\gamma$-terpinene, and limonene, induce structural and functional changes of the membrane [37]. Previous results indicated that certain properties of the compounds, such as hydrophobicity and lipophobicity, also significantly influence on their antimicrobial potency. These properties allow them to penetrate through the membrane consequently changing the fluidity, permeability, protein properties, etc. [38]. There are reports which indicate that mixture of two or several terpenes showed higher activity than each one separately [39]. Therefore, synergistic effect should be also taken into an account when comparing the activity of these oils, especially because their chemical composition is different, i.e., different compounds were found in $\mathrm{SRB}$ and RF. Thus, it has been reported that p-cymene increases the antimicrobial activity of other compounds [34]. This could be, besides synergy, one of the possible explanations for significantly higher activity of RF comparing to the SRB oil.

Besides the chemical composition, some papers confirm the influence of geographical origin [3,4], seasonal variations [2], as well as varieties in rosemary [1,4] on the antimicrobial performance of rosemary's EO.

After the satisfactory results of preliminary examination by disk-diffusion method, microdilution methods were applied for further investigation of the antimicrobial activity. From the results presented in Table 4 it could be noted that SRB showed good antimicrobial activity against bacteria (MIC $\leq 50 \%$ ), while in the case of the eukaryotic microorganisms the activity was moderate (MIC $>50 \%$ ). Moderate activity against eu- 
caryotic organisms could be attributed to their complex cell structure [40]. In contrast, a very low MIC (below 6.3\%) of RF was noted for all selected microorganisms. The obtained results indicating a high antimicrobial activity of SRB and RF are in a good correlation with previously reported studies [2,3]. Such a great antimicrobial performance of the tested EO may contribute to their use in reducing foodborne pathogens and extending shelf life of food products or as a potential natural and green replacement of synthetic antibiotics, antimycotics, and preservatives in food and cosmetics industry.

Table 4. Minimal inhibitory concentration (MIC) of rosemary EO from Serbia (SRB) and Russia (RF) assayed by the microdilution method.

\begin{tabular}{|c|c|c|c|}
\hline \multirow{3}{*}{ Group } & \multirow{3}{*}{ Tested Strains } & \multicolumn{2}{|c|}{ MIC [\%] } \\
\hline & & \multicolumn{2}{|c|}{ Tested Samples of EO } \\
\hline & & SRB & RF \\
\hline \multirow{2}{*}{$\mathrm{G}(-)$ bacteria } & E. coli ATCC 25922 & 12.5 & 0.8 \\
\hline & P. aeruginosa ATCC 27853 & 50.0 & 6.3 \\
\hline \multirow{2}{*}{$\mathrm{G}(+)$ bacteria } & B. cereus ATCC 11778 & 12.5 & 0.8 \\
\hline & S.aureus ATCC 25923 & 6.3 & 0.8 \\
\hline Yeast & S. cerevisiae ATCC 9763 & $>50.0$ & 1.6 \\
\hline Fungi & A. brasiliensis ATCC 16404 & $>50.0$ & 1.6 \\
\hline
\end{tabular}

\subsection{Thermal Analysis of Essential Oils}

\subsubsection{Thermal Properties}

After the initial evaluation (chemical composition and antimicrobial activity), the next step was to determine the thermal properties. These are quite important data because application of these oils would depend on their stability and evaporation. Obtained results are listed in Table 5, and corresponding curves are shown in Figure 1a. The shape of all curves was almost identical for both EOs indicating that analyzed EOs have similar thermal characteristics. This is rather expected given that the most prevalent components were the same in both EOs (Table 1). One wide endothermic peak, in the range of about 150 to $250{ }^{\circ} \mathrm{C}$ for SRB and about 170 to $260{ }^{\circ} \mathrm{C}$ for RF, appeared on both DSC curves, which corresponded to the process of evaporation $[17,22]$. The main step of this process (temperature range from Ton to Toff) of the SRB EO was wider than one of RF EO, which was expected, because more components were detected in SRB by GC-MS analysis. The evaporation process in SRB EO began at a lower temperature than in RF EO (Ton,SRB < Ton, RF, $p<0.05$ ), and in both EOs it ended at approximately the same temperature $(p<0.05)$. The boiling temperatures of the predominant components of both samples varied from about 166 to $264{ }^{\circ} \mathrm{C}$ [41], which is in accordance with a temperature range of the EOs evaporation process determined by the DSC method.

One mass loss and one peak were detected on the TG and differential TG curves for both samples, respectively, indicating that the evaporation occurred in one step (Figure 1b). Both EOs evaporated completely to about $120^{\circ} \mathrm{C}$, with the residue of 1.5 to $2 \%$. The peak temperature $\left(T_{p}\right)$ on the DTG curve represents the temperature at which the evaporation process was fastest. $\mathrm{T}_{\mathrm{p}}$ of SRB EO was lower than $\mathrm{T}_{\mathrm{p}}$ of RF EO (Table $1, p<0.05$ ), indicating that the evaporation process in SRB EO reached a maximum rate at a lower temperature compared to RF EO. This is consistent with the DSC results that the evaporation process in SRB EO begins at a lower temperature compared to RF EO. 
Table 5. Results of thermal analysis (DSC and TGA) of Russian and Serbian rosemary essential oils.

\begin{tabular}{ccc}
\hline Parameters & SRB & RF \\
\hline & DSC & \\
\hline $\mathrm{T}_{\text {on }}\left({ }^{\circ} \mathrm{C}\right)$ & $179 \pm 1^{\mathrm{b}}$ & $192 \pm 2^{\mathrm{a}}$ \\
$\mathrm{T}_{\mathrm{p}}\left({ }^{\circ} \mathrm{C}\right)$ & $204 \pm 2^{\mathrm{b}}$ & $207 \pm 1^{\mathrm{a}}$ \\
$\mathrm{T}_{\text {off }}\left({ }^{\circ} \mathrm{C}\right)$ & $223 \pm 2^{\mathrm{a}}$ & $221 \pm 1^{\mathrm{a}}$ \\
$\Delta \mathrm{H}(\mathrm{J} / \mathrm{g})$ & $320 \pm 10^{\mathrm{a}}$ & $256 \pm 9^{\mathrm{b}}$ \\
\hline & $\mathrm{TGA}$ & $74 \pm 1^{\mathrm{a}}$ \\
\hline $\mathrm{T}_{\mathrm{p}}\left({ }^{\circ} \mathrm{C}\right)$ & $71 \pm 2^{\mathrm{b}}$ & $30 \pm 3^{\mathrm{a}}$ \\
$\mathrm{T}_{\mathrm{s}}\left({ }^{\circ} \mathrm{C}\right)$ & $29 \pm 2^{\mathrm{a}}$ & $122 \pm 2^{\mathrm{a}}$ \\
$\mathrm{T}_{\mathrm{e}}\left({ }^{\circ} \mathrm{C}\right)$ & $121 \pm 2^{\mathrm{a}}$ & $1.5 \pm 0.3^{\mathrm{a}}$ \\
\hline Residue at $\mathrm{T}_{\mathrm{e}}(\%)$ & $1.9 \pm 0.5^{\mathrm{a}}$ &
\end{tabular}

Values are presented as mean \pm standard deviation $(n=3)$, different lowercase superscript within the same row indicate a significant difference of means according to Tukey's honest significant difference (HSD) test $(p<0.05)$. $\mathrm{T}_{\text {on }}$-onset temperature, $\mathrm{T}_{\text {off }}$-offset temperature, $\mathrm{T}_{\mathrm{p}}$ - peak temperature, $\mathrm{T}_{\mathrm{s}}$ - start temperature, $\mathrm{T}_{\mathrm{e}}$-end temperature.
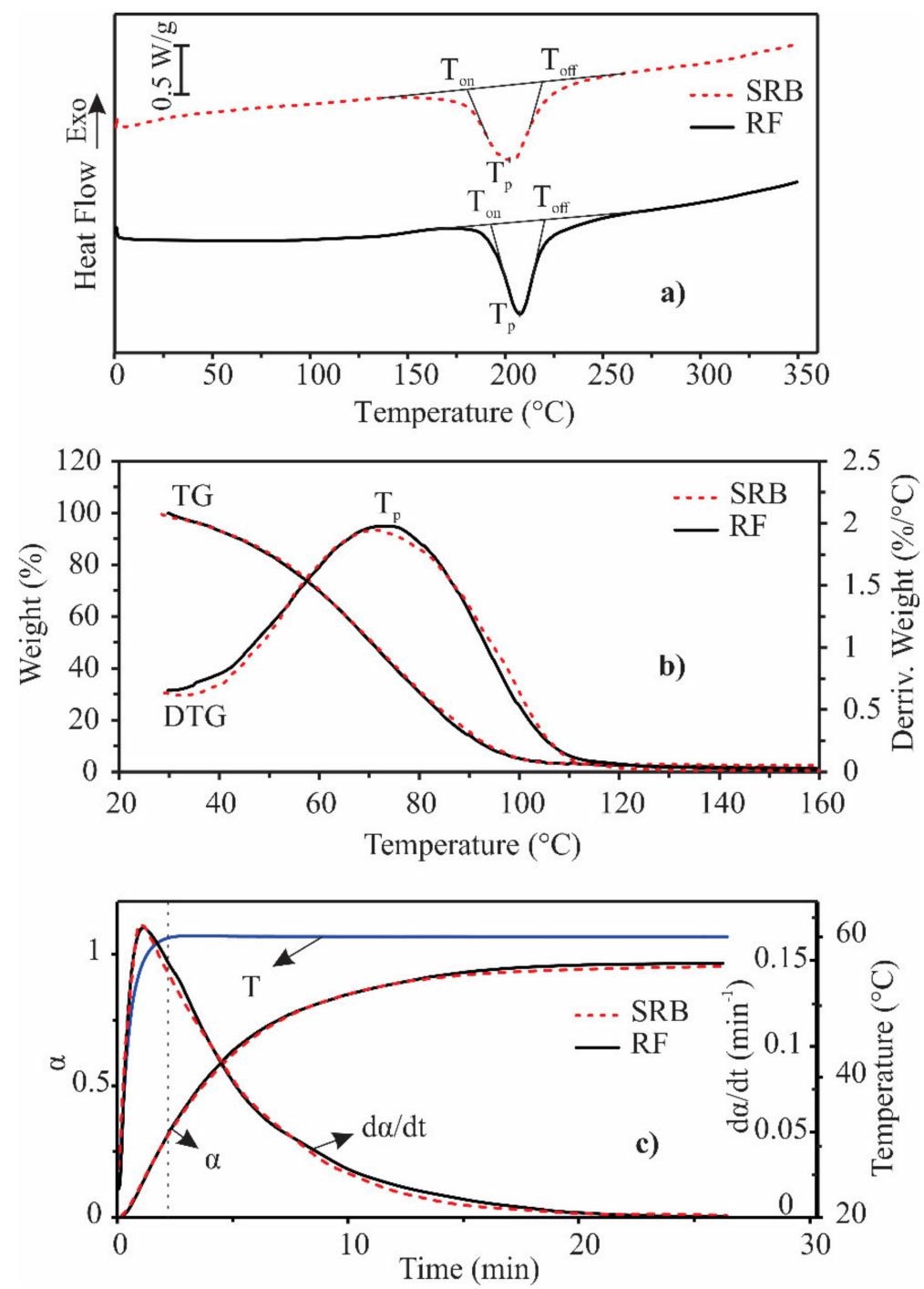

Figure 1. (a) DSC and (b) TG/DTG curves of Russian (RF) and Serbian (SRB) rosemary essential oils in non-isothermal condition at heating rate of $5{ }^{\circ} \mathrm{C} / \mathrm{min}$; (c) degree of conversion ( $\alpha$ ), evaporation rate $(\mathrm{d} \alpha / \mathrm{dt})$ and temperature $(\mathrm{T})$ as a function of time in isothermal condition at $60{ }^{\circ} \mathrm{C}$ for $\mathrm{RF}$ and SRB rosemary essential oils (beginning of isothermal conditions is marked by a vertical dashed line). Abbreviations: DSC—differential scanning calorimetry, TG—-thermogravimetry, DTG—differential thermogravimetry. 
Thermal characteristics of analyzed EOs were also examined in isothermal conditions at $60{ }^{\circ} \mathrm{C}$ (Figure 1c). The EOs showed almost identical thermal properties under these conditions, too. About 35\% of both EOs evaporated by the time the isothermal conditions were reached (about $2.5 \mathrm{~min}$ ). Both EOs completely evaporated in about $25 \mathrm{~min}$ (extent of conversion $-\alpha$ reached value 1 ). The rate of the evaporation process under isothermal conditions $(\mathrm{d} \alpha / \mathrm{dt})$ was maximal at the beginning and decreased with time, indicating a decelerating type of kinetic model for the process of the evaporation [42]. The explanation for such behavior is that in the beginning, more volatile components evaporate. As they leave the system, less volatile compounds persist in the EOs over time, causing the evaporation rate to decrease. This is in accordance with the literature data for laurel, sage, and coriander EOs, whose evaporation process demonstrated a decelerating type of kinetic model, too $[17,22]$.

The activation energies (Ea) of the evaporation obtained by the Friedman method [19] were in range from 52.5 to $72.6 \mathrm{~kJ} / \mathrm{mol}$ for $\mathrm{RF} \mathrm{EO}$, and from 53.8 to $67.9 \mathrm{~kJ} / \mathrm{mol}$ for SRB EO. In the literature, the activation energy of evaporation for pure substances is associated with the enthalpy $[43,44]$. The enthalpies of evaporation of the most prevalent compounds ranged from 37.9 to $52.8 \mathrm{~kJ} / \mathrm{mol}$ for both oils [41]. These values are slightly lower than the experimentally obtained activation energies of the essential oils' evaporation process. However, it should be kept in mind that essential oils are complex systems consisting of dozens of different components. These components in the system can physically interact, which can affect their evaporation process. Therefore, they can affect the activation energies of the essential oil evaporation process, which should essentially be the average value of the evaporation enthalpies of individual components of essential oil. Ea values did not vary significantly with the increase in the extent of conversion $(\alpha)$, for both EOs (Figure 2).

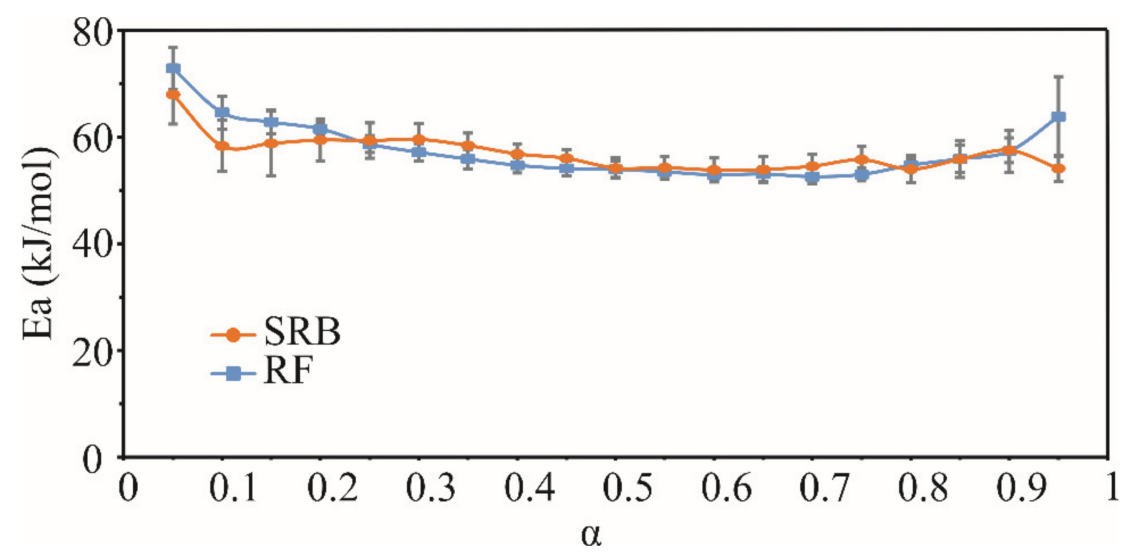

Figure 2. Activation energies (Ea) of the evaporation process of Russian (RF) and Serbian (SRB) rosemary essential oils as a function of conversion degree $(\alpha)$.

Such results imply that the process of the evaporation is a single-step process, which is consistent with the non-isothermal TGA results. The average activation energies in the tested EOs, $57.5 \pm 5.4 \mathrm{~kJ} / \mathrm{mol}$ for RF and $56.9 \pm 3.4 \mathrm{~kJ} / \mathrm{mol}$ for SRB, were not significantly different from each other $(p<0.05)$, which is another confirmation that these oils have very similar thermal properties.

\subsubsection{The Effect of Added RF and SRB EO on the Oxidative Stability of Sunflower Oil}

Finally, investigated essential oils were added to the sunflower oil in different percentages in order to investigate the possibility of EOs utilization as an antioxidant agent during the frying process. The effect of analyzed essential oils in sunflower oil on its oxidative stability was investigated by determining the oxidation induction time (OIT) using DSC in isothermal conditions at $140{ }^{\circ} \mathrm{C}$. DSC is a suitable technique for this purpose, because it simulates the real conditions of using edible oils at high temperatures during heat treatment of foods. The DSC curves of the oxidation process of pure sunflower oil and oil samples containing 1\% EO are shown in the Figure 3. 


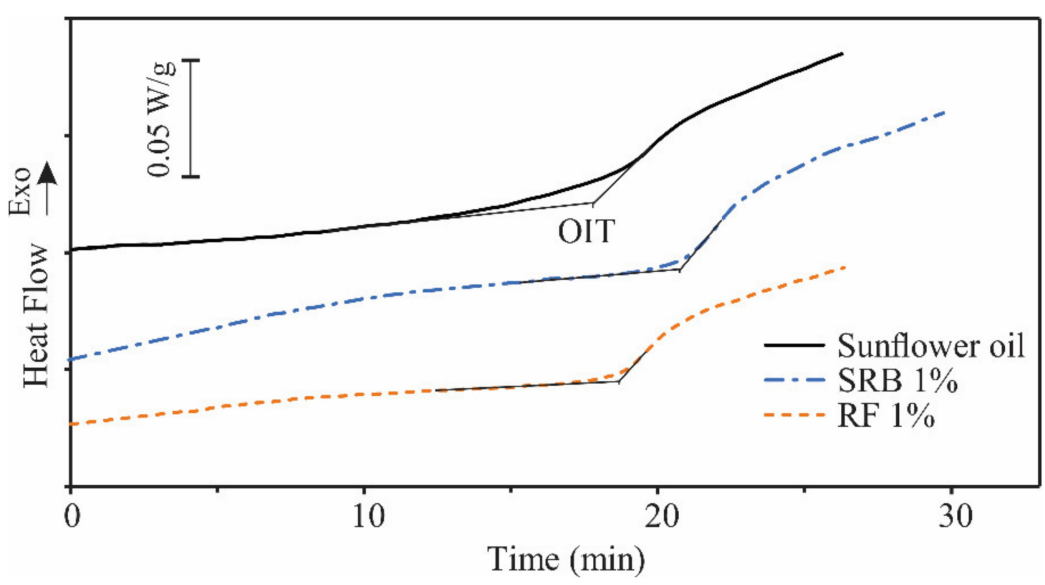

Figure 3. Isothermal DSC oxidation curves of pure sunflower oil and sunflower oil with added Russian (RF) and Serbian (SRB) rosemary essential oil with share of $1 \%(w / w)$ at $140{ }^{\circ} \mathrm{C}$ in oxygen flow $50 \mathrm{~mL} / \mathrm{min}$, OIT—oxidation induction time.

The effect of five different concentrations $(0.1,0.5,1,5$ and $10 \%(w / w))$ was examined, and the obtained results are shown in Table 6. It might be seen that, at concentrations of 0.1 , 0.5 and $1 \%$ of RF, this oil did not have a significant effect on the OIT values of sunflower oil $(p<0.05)$.

Table 6. Oxidation induction time (OIT) of sunflower oil with different share of added Russian (RF) and Serbian (SRB) essential oils.

\begin{tabular}{|c|c|c|}
\hline \multirow{2}{*}{ Percentage of Added EO (\% $w / w)$} & \multicolumn{2}{|c|}{ OIT (min) } \\
\hline & SRB & RF \\
\hline 0 & \multicolumn{2}{|c|}{$18 \pm 1$} \\
\hline 0.1 & $19.4 \pm 0.8^{\mathrm{AB}, \mathrm{a}}$ & $20 \pm 1^{\mathrm{A}, \mathrm{a}}$ \\
\hline 0.5 & $20.7 \pm 0.8^{\mathrm{AB}, \mathrm{a}, *}$ & $20.2 \pm 0.2^{\mathrm{A}, \mathrm{a}}$ \\
\hline 1 & $21 \pm 1^{\mathrm{A}, \mathrm{a}, *}$ & $18.5 \pm 0.4^{\mathrm{A}, \mathrm{b}}$ \\
\hline 5 & $18.3 \pm 0.6^{\mathrm{BC}, \mathrm{a}}$ & $10.8 \pm 0.8^{\mathrm{B}, \mathrm{b}, *}$ \\
\hline 10 & $16.3 \pm 0.8^{\mathrm{C}, \mathrm{a}}$ & $5 \pm 1^{C, b, *}$ \\
\hline
\end{tabular}

Values are presented as mean \pm standard deviation $(n=3)$, different uppercase superscript within the same column indicate a significant difference of means, different lowercase superscript within the same row indicate a significant difference of means, and asterisk $\left(^{*}\right)$ indicate a significant difference of means between all samples and sunflower oil without essential oil according to Tukey's honest significant difference (HSD) test $(p<0.05)$.

Concentrations of 5 and $10 \%$ significantly reduced the OIT value compared to pure sunflower oil $(p<0.05)$. The OIT value was reduced about 1.7 times by adding $5 \%$ of RF $\mathrm{EO}$ and even 4 times by adding $10 \%$ of $\mathrm{RF} \mathrm{EO}$, indicating that increasing the concentration of RF EO significantly reduced the quality of sunflower oil in terms of its oxidative stability. In the case of SRB EO, concentrations of $0.1,5$ and $10 \%$ did not have a significant effect on OIT values compared to pure sunflower oil $(p<0.05)$. Concentrations of 0.5 and $1 \%$ slightly increased the OIT value $(p<0.05)$, indicating that they improved the quality of sunflower oil in terms of its oxidative stability. Based on these results, it can be concluded that the addition of SRB EO in a certain concentration can improve the oxidative stability of sunflower oil, and thus its quality. While the addition of RF EO in smaller concentrations does not affect the oxidative stability of sunflower oil, higher concentrations can significantly impair it. The reason for such a different effect on the oxidative stability of sunflower oil could be the presence of different minor components in analyzed EO, since both EOs, RF and SRB, have a similar content of the predominant components.

Positive effect of rosemary essential oil on stability of hazelnuts and poppy oils was previously reported [45]. There is also report of high protection activity of rosemary oil in sunflower oil against oxidation [46]. However, authors investigated antioxidant influence by periodic determination of peroxide value, which is simple volumetric method (titration) 
after exposing the samples at $50{ }^{\circ} \mathrm{C}$. In this case, investigation has been performed at $140{ }^{\circ} \mathrm{C}$, which is more suitable and simulates the cooking processes which include sunflower oil. In this case, antioxidant activity is very important for this role. It has been reported that carvone, myrcene, and $\gamma$-terpinene scavenge DPPH radicals very quickly. It was also shown that terpenes with conjugated double bonds had very high antioxidant potency [47]. In this case presence of such compounds was noticed in both oils, but SRB showed better activity in this case because of the higher content of these compounds in it.

\section{Conclusions}

Investigation of the influence geographical origin on the chemical profile of the rosemary oil indicated the discrepancies in both composition and in content of the identified compounds in analyzed samples. Although the same compounds were the most abundant one in both oils ( $\alpha$-pinene, eucalyptol, and camphor), both oils had specifical compounds which could be detected in only one sample but not in the other. Such diversity significantly influenced the properties of the oils. Therefore, Russian oil (RF) showed significantly higher antimicrobial activity against all tested strains. On the other hand, when oils were injected into a sunflower oil, Serbian oil (SRB) proved to be more potent as antioxidant agent, while RF did not affect the stability in minor concentrations, but decreased oxidative stability of sunflower oil in higher concentrations. Therefore, application of the essential oil would highly depend on the chemical composition and oils have to be properly investigated prior to decision of the field of application. However, the result presented herein showed high potential of the rosemary as an antioxidant and antimicrobial agent. This implies possible application for different purposes, such as a natural preservative agent, to be used instead of artificial agents which may be harmful for human health.

Supplementary Materials: The following are available online at https:/ / www.mdpi.com/article / 10.3390/foods10112734/s1, Figure S1: Chromatograms of Serbian (upper) and Russian (bottom) essential oils. TIC values for Serbian and Russian oils were $8.90 \times 107$ and $6.69 \times 107$, respectively, Table S1: Retention time, ion fragments, and identification methods for rosemary essential oils.

Author Contributions: Conceptualization, S.Đ.; methodology, S.Đ. and D.M.; software, D.M.; formal analysis, S.Đ., D.M., P.R., A.T., O.Š., S.F., T.T., S.F. and B.D.; investigation, R.B. and D.J.; resources, S.B.; data curation, S.Đ., D.M., A.T. and O.Š.; writing-original draft preparation, S.Đ., O.Š., A.T., D.M. and S.F.; writing-review and editing, S.Đ., O.Š., A.T., D.M. and S.F.; visualization, S.Đ., D.M., A.T. and S.F.; supervision, S.Đ.; project administration, S.Đ.; funding acquisition, S.B. All authors have read and agreed to the published version of the manuscript.

Funding: The authors would like to thank the Ministry of Education, Science, and Technological Development of Republic of Serbia (Grants No: 451-03-9/2021-14/200051, 451-03-9/2021-14/200134, and 451-03-9/2021-14/200026, and 451-03-9/2021-14/200168) for financial support.

Conflicts of Interest: The authors declare no conflict of interest.

\section{References}

1. Zaouali, Y.; Bouzaine, T.; Boussaid, M. Essential oils composition in two Rosmarinus officinalis L. varieties and incidence for antimicrobial and antioxidant activities. Food Chem. Toxicol. 2010, 48, 3144-3152. [CrossRef] [PubMed]

2. Lemos, M.F.; Lemos, M.F.; Pacheco, H.P.; Endringer, D.C.; Scherer, R. Seasonality modifies rosemary's composition and biological activity. Ind. Crops Prod. 2015, 70, 41-47. [CrossRef]

3. Jordán, M.J.; Lax, V.; Rota, M.C.; Lorán, S.; Sotomayor, J.A. Effect of the phenological stage on the chemical composition, and antimicrobial and antioxidant properties of Rosmarinus officinalis L essential oil and its polyphenolic extract. Ind. Crops Prod. 2013, 48, 144-152. [CrossRef]

4. Bajalan, I.; Rouzbahani, R.; Pirbalouti, A.G.; Maggi, F. Antioxidant and antibacterial activities of the essential oils obtained from seven Iranian populations of Rosmarinus officinalis. Ind. Crops Prod. 2017, 107, 305-311. [CrossRef]

5. Pellegrini, M.; Ricci, A.; Serio, A.; Chaves-López, C.; Mazzarrino, G.; D’Amato, S.; Lo Sterzo, C.; Paparella, A. Characterization of Essential Oils Obtained from Abruzzo Autochthonous Plants: Antioxidant and Antimicrobial Activities Assessment for Food Application. Foods 2018, 7, 19. [CrossRef] [PubMed]

6. Teixeira, B.; Marques, A.; Ramos, C.; Neng, N.R.; Nogueira, J.M.F.; Saraiva, J.A.; Nunes, M.L. Chemical composition and antibacterial and antioxidant properties of commercial essential oils. Ind. Crops Prod. 2013, 43, 587-595. [CrossRef] 
7. Karakaya, S.; El, S.N.; Karagozlu, N.; Sahin, S.; Sumnu, G.; Bayramoglu, B. Microwave-assisted hydrodistillation of essential oil from rosemary. J. Food Sci. Technol. 2014, 51, 1056-1065. [CrossRef]

8. Bousbia, N.; Abert Vian, M.; Ferhat, M.A.; Petitcolas, E.; Meklati, B.Y.; Chemat, F. Comparison of two isolation methods for essential oil from rosemary leaves: Hydrodistillation and microwave hydrodiffusion and gravity. Food Chem. 2009, 114, 355-362. [CrossRef]

9. Wang, D.; Fan, W.; Guan, Y.; Huang, H.; Yi, T.; Ji, J. Oxidative stability of sunflower oil flavored by essential oil from Coriandrum sativum L. during accelerated storage. LWT 2018, 98, 268-275. [CrossRef]

10. Chen, X.; Zhang, Y.; Zu, Y.; Yang, L.; Lu, Q.; Wang, W. Antioxidant effects of rosemary extracts on sunflower oil compared with synthetic antioxidants. Int. J. Food Sci. Technol. 2014, 49, 385-391. [CrossRef]

11. Mezza, G.N.; Borgarello, A.V.; Grosso, N.R.; Fernandez, H.; Pramparo, M.C.; Gayol, M.F. Antioxidant activity of rosemary essential oil fractions obtained by molecular distillation and their effect on oxidative stability of sunflower oil. Food Chem. 2018, 242, 9-15. [CrossRef] [PubMed]

12. Kamkar, A.; Javan, A.J.; Asadi, F.; Kamalinejad, M. The antioxidative effect of Iranian Mentha pulegium extracts and essential oil in sunflower oil. Food Chem. Toxicol. 2010, 48, 1796-1800. [CrossRef]

13. Lercker, G.; Rodriguez-Estrada, M.T. Cholesterol oxidation mechanisms. In Cholesterol and Phytosterol Oxidation Products: Analysis, Occurrence, and Biological Effects; Guardiola, F., Dutta, P.C., Codony, R., Savage, G.P., Eds.; AOCS Press: Champaign, IL, USA, 2002; pp. 1-25.

14. Sikwese, F.E.; Duodu, K.G. Antioxidant effect of a crude phenolic extract from sorghum bran in sunflower oil in the presence of ferric ions. Food Chem. 2007, 104, 324-331. [CrossRef]

15. Padmashree, A.; Roopa, N.; Semwal, A.D.; Sharma, G.K.; Agathian, G.; Bawa, A.S. Star-anise (Illicium verum) and black caraway (Carum nigrum) as natural antioxidants. Food Chem. 2007, 104, 59-66. [CrossRef]

16. Wang, D.; Meng, Y.; Zhao, X.; Fan, W.; Yi, T.; Wang, X. Sunflower oil flavored by essential oil from Punica granatum cv. Heyinshiliu peels improved its oxidative stability and sensory properties. LWT 2019, 111, 55-61. [CrossRef]

17. Micić, D.; Ostojić, S.; Pezo, L.; Blagojević, S.; Pavlić, B.; Zeković, Z.; Đurović, S. Essential oils of coriander and sage: Investigation of chemical profile, thermal properties and QSRR analysis. Ind. Crops Prod. 2019, 138, 111438. [CrossRef]

18. Šojić, B.; Pavlić, B.; Tomović, V.; Ikonić, P.; Zeković, Z.; Kocić-Tanackov, S.; Đurović, S.; Škaljac, S.; Jokanović, M.; Ivić, M. Essential oil versus supercritical fluid extracts of winter savory (Satureja montana L.) -Assessment of the oxidative, microbiological and sensory quality of fresh pork sausages. Food Chem. 2019, 287, 280-286. [CrossRef]

19. Friedman, H.L. Kinetics of thermal degradation of char-forming plastics from thermogravimetry. Application to a phenolic plastic. J. Polym. Sci. Part C Polym. Symp. 1964, 6, 183-195. [CrossRef]

20. Vyazovkin, S.; Chrissafis, K.; Di Lorenzo, M.L.; Koga, N.; Pijolat, M.; Roduit, B.; Sbirrazzuoli, N.; Suñol, J.J. ICTAC Kinetics Committee recommendations for collecting experimental thermal analysis data for kinetic computations. Thermochim. Acta 2014, 590, 1-23. [CrossRef]

21. Micić, D.M.; Ostojić, S.B.; Simonović, M.B.; Krstić, G.; Pezo, L.L.; Simonović, B.R. Kinetics of blackberry and raspberry seed oils oxidation by DSC. Thermochim. Acta 2015, 601, 39-44. [CrossRef]

22. Riabov, P.A.; Micić, D.; Božović, R.B.; Jovanović, D.V.; Tomić, A.; Šovljanski, O.; Filip, S.; Tosti, T.; Ostojić, S.; Blagojević, S.; et al. The chemical, biological and thermal characteristics and gastronomical perspectives of Laurus nobilis essential oil from different geographical origin. Ind. Crops Prod. 2020, 151, 112498. [CrossRef]

23. Pavlić, B.; Teslić, N.; Vidaković, A.; Vidović, S.; Velićanski, A.; Versari, A.; Radosavljević, R.; Zeković, Z. Sage processing from by-product to high quality powder: I. Bioactive potential. Ind. Crops Prod. 2017, 107, 81-89. [CrossRef]

24. Bozin, B.; Mimica-Dukic, N.; Samojlik, I.; Jovin, E. Antimicrobial and Antioxidant Properties of Rosemary and Sage (Rosmarinus officinalis L. and Salvia officinalis L., Lamiaceae) Essential Oils. J. Agric. Food Chem. 2007, 55, 7879-7885. [CrossRef]

25. Gachkar, L.; Yadegari, D.; Rezaei, M.; Taghizadeh, M.; Astaneh, S.; Rasooli, I. Chemical and biological characteristics of Cuminum cyminum and Rosmarinus officinalis essential oils. Food Chem. 2007, 102, 898-904. [CrossRef]

26. Stephanos, J.J.; Addison, A.W. Chemistry of Metalloproteins: Problems and Solutions in Bioinorganic Chemistry; John Wiley \& Sons: Hoboken, NJ, USA, 2014.

27. Đurović, S.; Pavlić, B.; Šorgić, S.; Popov, S.; Savić, S.; Petronijević, M.; Radojković, M.; Cvetanović, A.; Zeković, Z. Chemical composition of stinging nettle leaves obtained by different analytical approaches. J. Funct. Foods 2017, 32, 18-26. [CrossRef]

28. Roat-Malone, R.M. Bioinorganic Chemistry: A Short Course, 2nd ed.; John Wiley \& Sons: Hoboken, NJ, USA, 2007.

29. USDA-NAL. Dietary Reference Intakes (DRIs): Estimated Average Requirements. Available online: https://www.nal.usda.gov/ sites/default/files/fnic_uploads/recommended_intakes_individuals.pdf (accessed on 8 February 2021).

30. Abdollahi, M.; Rezaei, M.; Farzi, G. A novel active bionanocomposite film incorporating rosemary essential oil and nanoclay into chitosan. J. Food Eng. 2012, 111, 343-350. [CrossRef]

31. Deba, F.; Xuan, T.D.; Yasuda, M.; Tawata, S. Chemical composition and antioxidant, antibacterial and antifungal activities of the essential oils from Bidens pilosa Linn. var. Radiata. Food Control 2008, 19, 346-352. [CrossRef]

32. Griffin, S.G.; Wyllie, S.G.; Markham, J.L.; Leach, D.N. The role of structure and molecular properties of terpenoids in determining their antimicrobial activity. Flavour Fragr. J. 1999, 14, 322-332. [CrossRef]

33. Zengin, H.; Baysal, A. Antibacterial and antioxidant activity of essential oil terpenes against pathogenic and spoilage-forming bacteria and cell structure-activity relationships evaluated by SEM microscopy. Molecules 2014, 19, 17773-17798. [CrossRef] 
34. Trombetta, D.; Castelli, F.; Sarpietro, M.G.; Venuti, V.; Cristani, M.; Daniele, C.; Saija, A.; Mazzanti, G.; Bisignano, G. Mechanisms of Antibacterial Action of Three Monoterpenes. Antimicrob. Agents Chemother. 2005, 49, 2474-2478. [CrossRef]

35. Uribe, S.; Ramirez, J.; Peña, A. Effects of beta-pinene on yeast membrane functions. J. Bacteriol. 1985, 161, 1195-1200. [CrossRef] [PubMed]

36. Uribe, S.; Pena, A. Toxicity of allelopathic monoterpene suspensions on yeast dependence on droplet size. J. Chem. Ecol. 1990, 16, 1399-1408. [CrossRef] [PubMed]

37. Sikkema, J.; de Bont, J.A.; Poolman, B. Interactions of cyclic hydrocarbons with biological membranes. J. Biol. Chem. 1994, 269, 8022-8028. [CrossRef]

38. Andrade-Ochoa, S.; Nevárez-Moorillón, G.V.; Sánchez-Torres, L.E.; Villanueva-García, M.; Sánchez-Ramírez, B.E.; RodríguezValdez, L.M.; Rivera-Chavira, B.E. Quantitative structure-activity relationship of molecules constituent of different essential oils with antimycobacterial activity against Mycobacterium tuberculosis and Mycobacterium bovis. BMC Complement. Altern. Med. 2015, 15, 332. [CrossRef]

39. Bhavaniramya, S.; Vishnupriya, S.; Al-Aboody, M.S.; Vijayakumar, R.; Baskaran, D. Role of essential oils in food safety: Antimicrobial and antioxidant applications. Grain Oil Sci. Technol. 2019, 2, 49-55. [CrossRef]

40. Chouhan, S.; Sharma, K.; Guleria, S. Antimicrobial Activity of Some Essential Oils-Present Status and Future Perspectives. Medicines 2017, 4, 58. [CrossRef]

41. ChemSpider I Search and Share Chemistry. Available online: http://www.chemspider.com (accessed on 8 February 2021).

42. Vyazovkin, S.; Burnham, A.K.; Criado, J.M.; Pérez-Maqueda, L.A.; Popescu, C.; Sbirrazzuoli, N. ICTAC Kinetics Committee recommendations for performing kinetic computations on thermal analysis data. Thermochim. Acta 2011, 520, 1-19. [CrossRef]

43. Cheng, Y.; Huang, Y.; Alexander, K.; Dollimore, D. A thermal analysis study of methyl salicylate. Thermochim. Acta 2001, 367-368, 23-28. [CrossRef]

44. Prado, J.R.; Vyazovkin, S. Activation energies of water vaporization from the bulk and from laponite, montmorillonite, and chitosan powders. Thermochim. Acta 2011, 524, 197-201. [CrossRef]

45. Özcan, M.M.; Arslan, D. Antioxidant effect of essential oils of rosemary, clove and cinnamon on hazelnut and poppy oils. Food Chem. 2011, 129, 171-174. [CrossRef]

46. Özcan, M.; Akgül, A. Antioxidant activity of extracts and essential oils from Turkish spices on sunflower oil. Acta Aliment. 1995, $24,81-90$.

47. Wojtunik, K.A.; Ciesla, L.M.; Waksmundzka-Hajnos, M. Model Studies on the Antioxidant Activity of Common Terpenoid Constituents of Essential Oils by Means of the 2,2-Diphenyl-1-picrylhydrazyl Method. J. Agric. Food Chem. 2014, 62, 9088-9094. [CrossRef] [PubMed] 